DOI: $10.2478 / v 10025-007-0004-8$

JOURNAL OF WATER

AND LAND DEVELOPMENT

J. Water Land Dev. No. 10, 2006: 45-53

\title{
Impact of the WFD on agriculture in the Netherlands and possible effect-specific hydrological measures: the Dutch approach
}

\author{
Jan van BAKEL
}

Wageningen University and Research Centre, Alterra, Centre for Water and Climate

\begin{abstract}
The European Water Framework Directive can have enormous consequences for agriculture in the Netherlands. In parts of the country agriculture should be taken out of production because the nutrient loads to the surface water system are far too high. This doom scenario is of course undesired and a number of source-specific and effect-specific measures are necessary. The fate of nutrients in the soil is strongly interrelated with its hydrology. Directly, because nutrients are transported by water and the distribution of the residence time of drainage water is a good measure for the time behaviour of the nutrient loads to the surface water system. Longer residence time in the soil means more of nutrients applied by farmers but also a longer recovery period, after applying source-specific measures. In this paper three promising effect-specific hydrological measures are described buffer strips, retention strips, and controlled drainage.
\end{abstract}

Key words: irrigation, drainage, water management, nutrients, regulated outflow

\section{INTRODUCTION}

The objectives of the European Water Framework Directive 2000 (WFD) focus on sustainable water use by protection and improvement of the quality of water systems, more specific on river basins. In a tentative study, the consequences of the Water Framework Directive (WFD) for agriculture in the Netherlands were investigated (VAN DER BOLT et al., 2003). The study was confined to nutrients and pesticides in fresh water systems. In this paper, first the methodology of the study will be described. Next, the possible consequences of the WFD for agriculture in the Netherlands (which are considerable) will be outlined in more detail. Finally special attention will be given to three promising effect-specific hydrological measures: buffer strips, water purification strips and controlled drainage. 


\section{METHODOLOGY}

The methodology was as follows: a reference situation for the year 2015 has been defined. The impacts of the WFD were explored by means of four scenarios, compiled out of two different classifications into areas/water bodies (18 and 90 areas, respectively) and two different ambition levels of ecological objectives (A and B). To each area a water type was allocated. Ambition level A represents a minimum Good Ecological Status (GES) for natural waters and a Good Ecological Potential (GEP) for heavily modified and artificial waters; ambition level B represents the High Ecological Status (HES) and Maximum Ecological Potential (MEP). In order to meet the ecological objectives the WFD results in additional requirements to chemical water quality, including maximum concentrations of nutrients which vary in accordance with the water types. The ratio between the chemical critical load and the load in the reference situation in 2015 sets the reduction target per scenario. Measures will become imperative when the maximum concentrations are exceeded. In the study, agriculture was considered to be the main diffuse source. As will be shown in the next paragraph, maximum nutrient concentrations predominantly determine the impact of the WFD on agriculture.

\section{WFD CONSEQUENCES FOR AGRICULTURE}

The discrepancy between the nitrate loads in the reference situation of 2015 and the ecological requirements for the water quality is already large at ambition level A For level B the reduction levels are even more ambitious. In Figure 1, the ratios of the actual $\mathrm{N}$ loads in 2015 and the required $\mathrm{N}$ loads for both ambition levels are given.

As can be seen, the possible consequences of the WFD are considerable. In larger parts of the Netherlands, arable land should be taken out of production which is, of course, unacceptable. So, the question is how to avoid this doom scenario. The answer is to define a mixture of source-specific measurements and tailor made effect-specific measures. Therefore, the current environmental policy to reduce the use of nitrogen in agriculture will be continued. A number of source specific measures such as a ban to apply manure in winter periods will be fine tuned but it is to be expected that the environmental effects on the phosphate loads will be limited because the phosphate accumulation in soils mainly determine its leaching behaviour to the surface water system. In many soils, the phosphate stock is in the order of 50 years of phosphate uptake by plants and therefore source-specific measures have minor effects on the short and middle term. In search of possible solutions research has started to come with effect-specific (hydrological) measures. Three promising measures will be discussed in the next paragraph. 


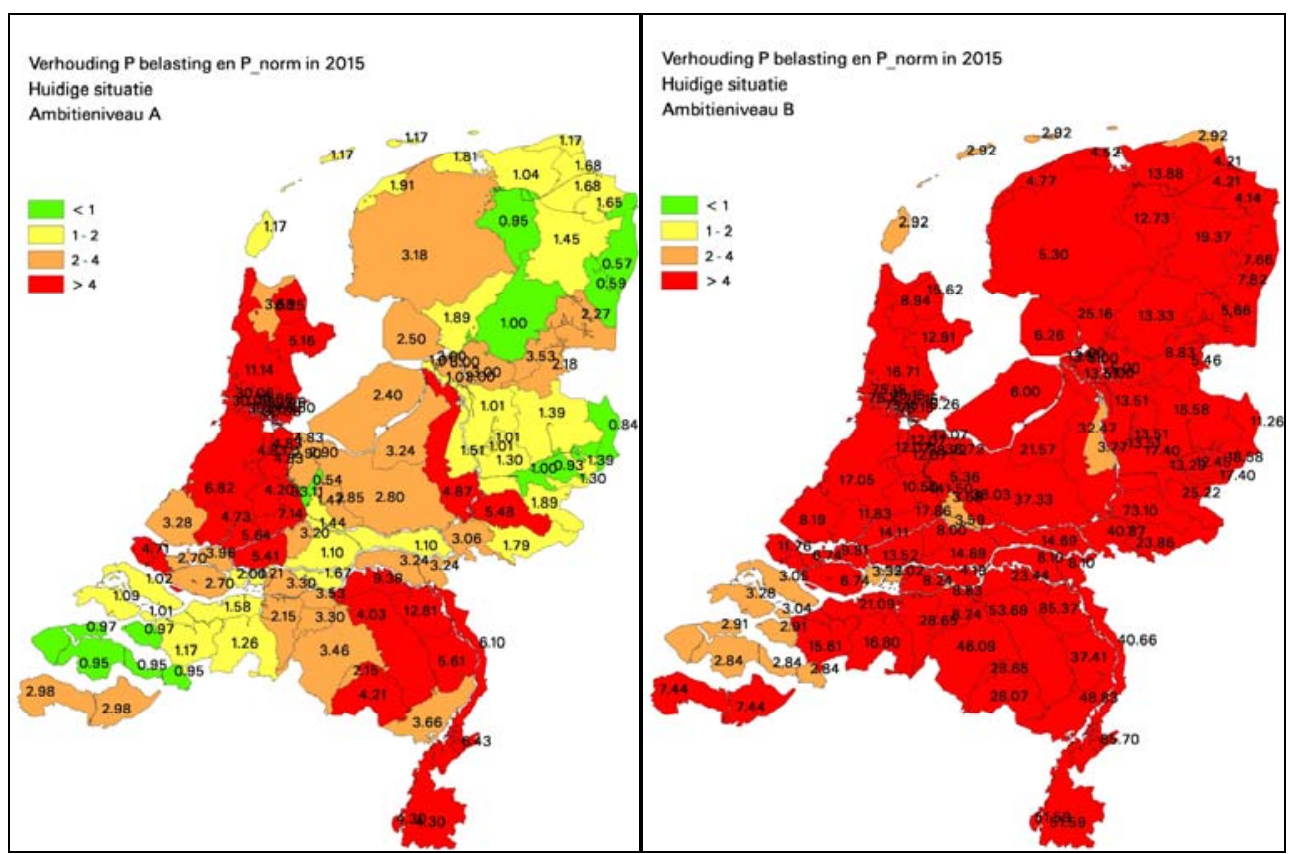

Fig. 1. Ratio between actual and required $\mathrm{N}$ loads in 2015 , for two ambition levels and the detailed scale level

\section{EFFECT-SPECIFIC MEASURES}

Introduction. The fate of nutrients in the soil is strongly interrelated with its hydrology. Directly, because nutrients are transported by water and the distribution of the residence time of drainage water is a good measure for the time behaviour of the nutrient loads to the surface water system. Longer residence time in the soil means more of nutrients applied by farmers but also a longer recovery period, after applying source-specific measures. Indirectly, the soil water status in the unsaturated soil strongly influences the chemical behaviour of nutrients in this soil compartment (KOOPMANS et al., 1997). A lot of knowledge about these subjects is applicable to define and design effect-specific measures. Three examples will be dealt with in this paragraph

Buffer strips. On the basis of a hydrological system analysis one can state that prominent sources for nutrients to the surface water are hydrological processes with a short residence time i.e.:

- surface runoff;

- interflow;

- water originating from a strip along water courses;

- drainage to shallow installed tile drains. 
In many parts of the Netherlands all or part of these processes are present so one obvious measure is to create buffer strips along water courses where no fertilisation will be applied and which are constructed in such a manner that surface runoff will be prevented (if runoff is to be expected). However, the cost efficiency of this rather costly measure is questionable. For many water courses are present in the agricultural areas. E.g. in the peat district in the western part of the Netherlands some $250 \mathrm{~m}$ of water courses per ha are present. A buffer strip of $4 \mathrm{~m}$ would imply that $20 \%$ of the land becomes buffer area. Moreover, the hydrological functioning of buffer strips in deep permeable soils or tile drained soils is assumed to be poor.

'Brussels' demands buffer strips of at least $5 \mathrm{~m}$ width along water courses. As was stated before, the implications for agriculture in the Netherlands can be considerable while the functioning is disputable Therefore, the Dutch Ministry of Agriculture, Nature and Food pled (and was permitted to do) for research into the functioning of these buffer strips with respect to the interception possibilities of nitrogen and phosphate. Therefore in 2005 an extensive research project was started.

An important pre-assumption for the research in that locations is that the nutrient load reduction capacity of buffer strips mainly depends on the geo-hydrological situation, the land use and the soil surface elevation properties. Therefore, on 5 places in the Netherlands, field experiments are set up.

The experimental results will be used to extrapolate to all the agricultural area using also results of model calculations.

Another pre-assumption is that buffer strips are less effective when tile drains are present. With tile drains water passes the buffer strip without having the possibility to enter the active part of the strip where roots can take up intercepted nutrients. But tile drains offer other interesting possibilities to reduce the nutrient loads to the surface water system, as will be explained in the next paragraph.

Retention strips. Because of climate change, a major concern of water managers is to reduce peak discharges. One possibility is to create extra retention capacity in water courses by creating a strip along the water course with a soil surface about $1 \mathrm{~m}$ below the land soil surface. A number of times during the year this strip will be flooded and in the periods in between the hydrological conditions are wet. This offers opportunities to create favourable conditions for denitrification. But the strip also is able to intercept (part of) the nutrients coming from the adjacent agricultural land. A promising measure is to grow and periodically harvest reed in the buffer strip. Reed is able to take up about $50 \mathrm{~kg}$ of $\mathrm{P}$ per ha per year.

Part of the nutrient load from adjacent agricultural land is supposed to be adsorbed to soil particles which enter the surface water system during periods of heavy storms (and consequently high water velocities in the surface water system). The reed can serve as a water velocity braker, so the soil particles can deposit. Therefore, the design of wet buffer strips is directed to favour interception of nutri- 
ents and deposition of eroded soil particles. In Figure 2 an example is presented of such an innovative design, which is now (April 2006) under construction, in the framework of a study on measures to reduce the P-loads to the surface water system in sandy regions in the eastern and southern parts of the Netherlands.

Both the incoming and outgoing discharges of the strip will be measured continuously and the nutrient concentrations will be sampled discharge-proportionally. In this way the interception capacity for phosphate and the retention capacity for nitrogen can be determined experimentally.

Controlled drainage. In particulary the sandy regions of the Netherlands in the upper 30 to $50 \mathrm{~cm}$ of the soil, large amounts of phosphate are accumulated, as a result of decades of surplus manuring with animal slurry. This phosphate becomes more mobile in wet conditions. So, structural lowering of the phreatic groundwater level can result in immobilisation of (part of) the phosphate stock. A well-known measure to lower the groundwater level is installing tile drains. A disadvantage can be that it leads to extra drought damage in agriculture and structural lowering of the groundwater level in adjacent nature areas, because of the interrelation via the regional groundwater system. Another possible negative effect is that the shortening of the average residence time in the groundwater system of the drained water leads to more chance for so-called short cuts (precipitation surplus flows via preferential pathways to the drains). This can be an important source for nutrient loads. So, the challenge is to design a tile drain system which lowers the highest groundwater levels, doesn't lower the average groundwater level and reduces the risk for short cuts. In the past in the Netherlands but also abroad the concept of controlled drainage is an accepted measure to favour agrohydrological conditions or to reduce environmental loads (Agricultural..., 1999; KALISVAART, 1958; VISSER, 1995). The system has adopted an combined with a design for composite drainage as developed by Van Iersel. The depth of the tile drains is more than usual: about $1.50 \mathrm{~m}$ instead of $1.0 \mathrm{~m}$, so the chance of short cuts is reduced.

With the agrohydrological model SWAP (VAN DAM and KROES, 2003) the effects of different types of design and water level manipulation on the groundwater levels are calculated. See Figure 3.

The groundwater levels can be expressed relative to the soil surface, i.e. groundwater depths. In the Netherlands specific characteristics are defined, viz. mean average highest groundwater depth (GHG; the average of the 3 highest phreatic groundwater levels measured (or simulated) each hydrological year with an interval of appr. 15 days, of a continuous time record of at least 8 years), mean average lowest groundwater depth (GLG; same definition for the 3 lowest)) and mean average groundwater depth (GG; the average of all measured or simulated levels). In Table the most important results are presented. Note that the surface runoff is almost eliminated by installing tile drains, even with a $0.40 \mathrm{~m}$ higher drainage basis. 


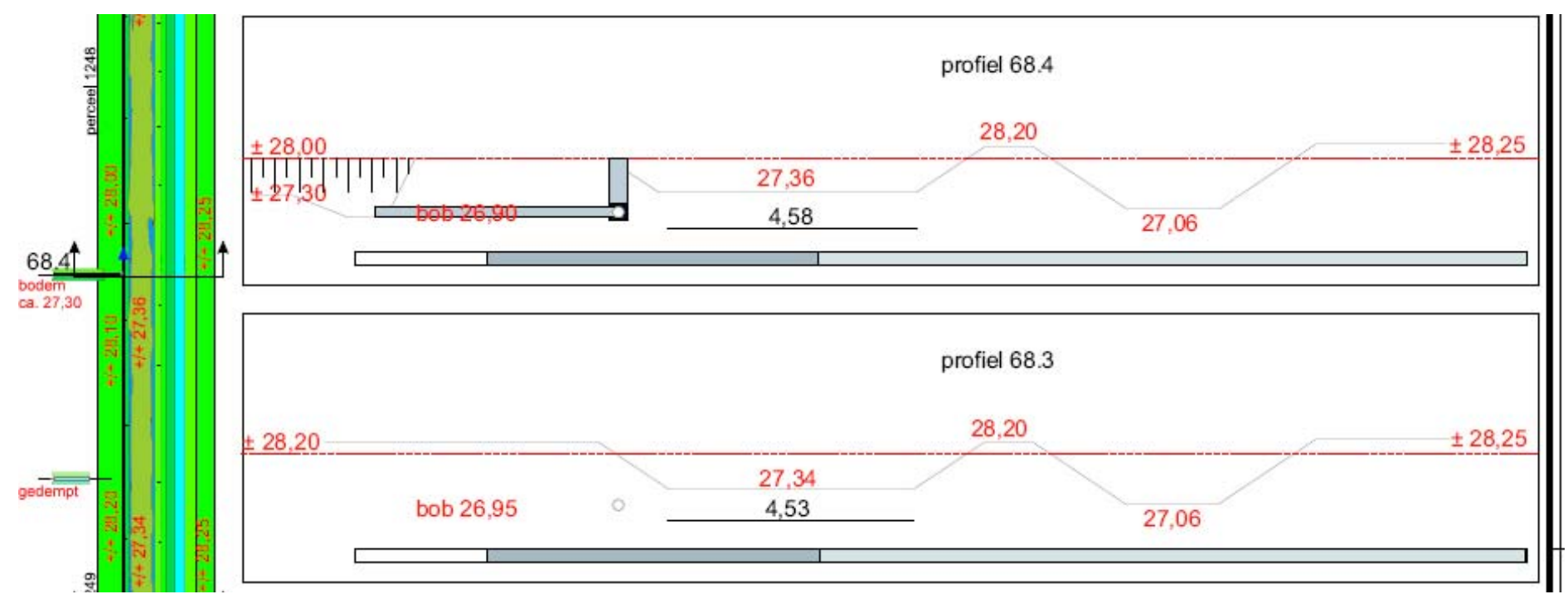

Fig. 2. Design of a water purification strip along a rivulet. In the strip reed will be planted and will be harvested periodically. On the left side water from a small water course is entering the strip 


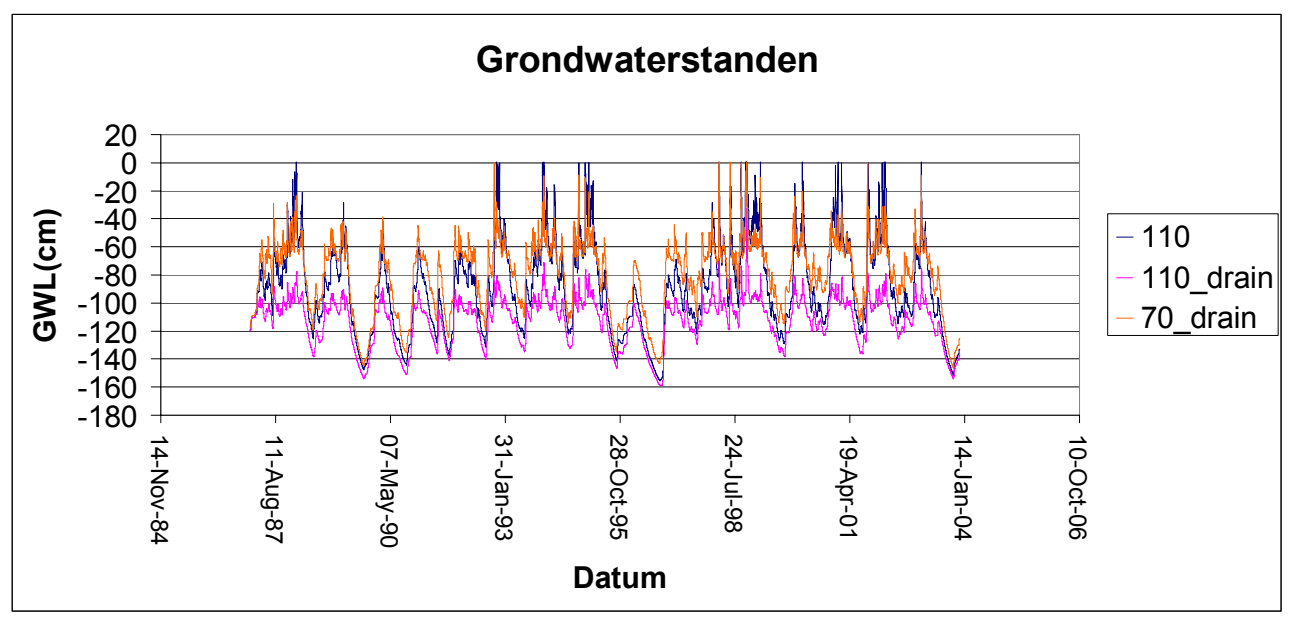

Fig. 3. Simulated groundwater levels for 3 types of three drainage situation (110 is reference situation; 110_drain is reference situation with tile drains and 70 drain is reference situation with tile drains and a $0.40 \mathrm{~m}$ higher drainage basis)

Table 1. Effect of different types of water management on some characteristics of the ground water depth

\begin{tabular}{l|c|c|c|c}
\hline & $\begin{array}{c}\text { GHG (m minus } \\
\text { soil surface) }\end{array}$ & $\begin{array}{c}\text { GLG (m minus } \\
\text { soil surface) }\end{array}$ & $\begin{array}{c}\text { GG (m minus } \\
\text { soil surface }\end{array}$ & $\begin{array}{c}\text { Average surface } \\
\text { runoff } \\
\mathrm{mm}^{-1} \mathrm{y}^{-1}\end{array}$ \\
\hline $\begin{array}{l}\text { Reference situation, drainage } \\
\text { basis } 1.10 \text { m minus soil } \\
\text { surface) }\end{array}$ & 0.45 & 1.23 & 0.90 & 22 \\
$\begin{array}{l}\text { Reference situation tile drained } \\
\begin{array}{l}\text { Reference situation, tile } \\
\text { drained and drainage basis }\end{array}\end{array}$ & 0.92 & 1.33 & 1.12 & 0 \\
\begin{tabular}{l}
0.70 m minus soil surface \\
\hline
\end{tabular} & 0.50 & 1.10 & 0.81 & 1 \\
\hline
\end{tabular}

It can be concluded that installing tile drainage without raising the drainage basis results in considerably lower groundwater levels which is good for immobilisation of phosphate but probably undesired for agriculture and nature. By raising the drainage basis with $0.40 \mathrm{~m}$ the average groundwater depth is even higher compared with the reference situation while the mean highest groundwater depth is lower. Also the simulated surface runoff, which is supposed to be a major source for nutrient loads, is reduced due to the installation of tile drains. The possibilities of manipulating the drainage basis and the effects on peak discharges are also investigated and the results can be supplied on request by e-mail. 


\section{CONCLUSION}

The European Water Framework Directive can have enormous consequences for agriculture in the Netherlands. In parts of the country agriculture should be taken out of production because the nutrient loads to the surface water system are far too high. This doom scenario is of course undesired and a number of sourcespecific and effect-specific measures are necessary. In this paper three promising effect-specific hydrological measures are described.

The title of this paper suggests that the consequences of the WFD for agriculture and possible solutions are special for the situation in the Netherlands. Is the agronomic and hydrological situation in the Netherlands so typical that we can speak of the Dutch approach?

\section{REFERENCES}

1. Agricultural drainage, 1999. Eds.: R.W. Skaggs, J. van Schilfgaarde, J.M. Bartels. Agronomy 38.

2. KalisvaArt C., 1958. Subirrigation in the Zuiderzee Polders. Publ. 2, ILRI, Wageningen.

3. Koopmans G.F., Schoumans O.F., Chardon W.J., 1997. Relation between phosphate accumulation, soil $\mathrm{P}$ levels and P leaching in agricultural land. Report / DLO Winand Staring Centre 146.

4. Van DAm J.C., Kroes J.G., 2003. Reference manual SWAP version 3.0.3. Alterra-report 773.

5. Van der Bolt F., van den Bosch R., Brock T., Hellegers P., KwaKernaAK C., Leenders D., SCHOUMANS O., VeRDONSCHOT P., 2003. Aquarein: gevolgen van de Europese Kaderrichtlijn Water voor landbouw, natuur, recreatie en visserij. Alterra-report 835 (in Dutch).

6. VISSER J., 1995. Some results of subirrigation in the IJsselmeerpolders in The Netherlands. In: Subirrigation and controlled drainage. Eds. H.W. Belcher en F.M. D'Itri. Lewis Publishers, Boca Raton, FL USA.

\section{STRESZCZENIE}

\section{Wpływ RDW na rolnictwo w Holandii i spodziewany wpływ działań z zakresu gospodarki wodnej}

Słowa kluczowe: gospodarka wodna, nawodnienia, nutrienty, odptyw regulowany, odwodnienia

We wstępnym studium wdrażania Ramowej Dyrektywy Wodnej zbadano konsekwencje RDW dla rolnictwa w Holandii. Badania dotyczyły głównie pierwiastków biogennych i pestycydów w systemach słodkowodnych. Europejska Ramowa Dyrektywa Wodna może mieć ogromne konsekwencje dla rolnictwa w Holandii. W części kraju rolnictwo powinno zaprzestać produkcji, ponieważ ładunki pierwiastków biogennych wnoszone do wód powierzchniowych są zbyt 
duże. Niezbędne są liczne zabiegi, dobrane stosownie do źródeł zagrożenia i do efektów. W pracy przedstawiono propozycje ograniczania ładunków poprzez regulowanie odpływu lub budowę pasów ochronnych.

Reviewers:

Prof. Waldemar Mioduszewski

Prof. Czestaw Przybyta 